FEDERAL RESERVE BANK OF SAN FRANCISCO

WORKING PAPER SERIES

\title{
Foreign Entry into Underwriting Services: Evidence from Japan's "Big Bang" Deregulation
}

\author{
Mark M. Spiegel \\ Federal Reserve Bank of San Francisco \\ Jose A. Lopez \\ Federal Reserve Bank of San Francisco
}

June 2009

Working Paper 2009-14

http://www.frbsf.org/publications/economics/papers/2009/wp09-14bk.pdf

The views in this paper are solely the responsibility of the authors and should not be interpreted as reflecting the views of the Federal Reserve Bank of San Francisco or the Board of Governors of the Federal Reserve System. This paper was produced under the auspices of the Center for Pacific Basin Studies within the Economic Research Department of the Federal Reserve Bank of San Francisco. 


\title{
Foreign Entry into Underwriting Services: Evidence from Japan’s “Big Bang” Deregulation
}

\author{
Jose A. Lopez and Mark M. Spiegel \\ Federal Reserve Bank of San Francisco
}

June 15, 2009

\begin{abstract}
We examine the impact of foreign underwriting activity on bond markets using issuelevel data in the Japanese "Samurai" and euro-yen bond markets. Firms choosing Japanese underwriters tend to be Japanese, riskier, and smaller. We find that Japanese underwriting fees, while higher overall on average, are actually lower after conditioning for issuer characteristics. Moreover, firms tend to sort properly in their choice of underwriter, in the sense that a switch in underwriter nationality would be predicted to result in an increase in underwriting fees. Finally, we conduct a matching exercise to examine the 1995 liberalization of foreign access to the "Samurai" bond market, using yen-denominated issues in the euro-yen market as a control. Foreign entry led to a statistically and economically significant decrease in underwriting fees in the Samurai bond market, as spreads fell by an average of 23 basis points. Overall, our results suggest that the market for underwriting services is partially segmented by nationality, as issuers appear to have preferred habitats, but entry increases market competition.
\end{abstract}

\footnotetext{
J.E.L. Classification: F34, G21, G24

Keywords: underwriting, Japan, securities, euro-yen, Samurai, difference-in-differences

Corresponding authors: Economic Research Department, Federal Reserve Bank of San Francisco, 101 Market Street, San Francisco, CA, 94105. jose.a.lopez@,sf.frb.org, mark.spiegel@sf.frb.org. Helpful comments were received from Yin Wong Cheung, Eiji Fujii, Hans Genberg, Galina Hale, Takeo Hoshi, Charles Horioka, Chris James, Oscar Jorda, Anil Kashyap, Matthew Slaughter, Rob Shimer, and Yishay Yafeh, as well as seminar participants at the NBER Japan Group, and the Hong Kong Monetary Authority. Christopher Candelaria provided excellent research assistance. The views in this paper are solely the responsibility of the authors and should not be interpreted as reflecting the views of the Federal Reserve Bank of San Francisco or the Board of Governors of the Federal Reserve System.
} 


\section{Introduction}

In 1996, Japanese Prime Minister Hashimoto announced a "big bang” set of reforms aimed at preventing further deterioration of Japanese financial markets and retaining Tokyo's place as a leading world financial center. One important component of the "big bang" reforms concerned opening Japanese securities markets to foreign participants. Various restrictions that had limited the activities of foreign issuers and underwriters were repealed during the 1990s, with restrictions on foreign participation in underwriting in the Samurai market being removed in mid-1995. While the pace of reform certainly accelerated subsequent to the 1996 announcement, the "big bang" deregulations are better perceived as the culmination of a long process of reforms that began long before the 1990s, but accelerated during that turbulent period [Hoshi and Kashyap (2001)].

The lifting of restrictions on foreign competition in Japanese securities markets was controversial. Japanese securities markets had already been liberalized in 1993, with the entry of Japanese commercial banks into underwriting services [Yasuda (2007)]. Underwriting activity was an important source of profitability for Japanese commercial banks experiencing pressure from bad loans associated with the collapse of the asset bubble at the start of the decade.

Japanese investment banks were also under pressure, partly due to the entry by commercial banks into underwriting activity earlier in the decade, but also because of the poor overall performance of the Japanese economy. These pressures culminated in the failures of Yamaichi and Dai-Ichi Securities in October of 1997. The poor conditions faced by Japanese investment banks, combined with the relatively rapid success of 
foreign underwriters in achieving substantial market share in Japanese securities markets, have led some to question whether Japanese securities markets will suffer from the socalled "Wimbledon effect," a term sometimes applied to the London securities market, where robust domestic financial activity is primarily underwritten by foreign investment banks [e.g. Pohl (2002)].

This paper examines the impact of foreign entry into Japanese underwriting activity subsequent to the "big bang" liberalizations of the 1990s, using data on yendenominated bonds in the Japanese Samurai and euro-yen markets. ${ }^{1}$ We first examine the characteristics of issues underwritten by domestic (Japanese) and foreign (non-Japanese) or mixed underwriters and the implications of issuer choice for underwriting fees in these three markets from 1996-2001, the period over which foreign underwriters had access to these markets. We use a two-step procedure, acknowledging the fact that the choice of domestic versus foreign underwriter is likely to reflect firm characteristics. We then examine the implications of using a foreign underwriter after conditioning for the factors leading to the issuing firm's underwriter choice. Surprisingly, despite the fact that fees charged by Japanese underwriters are larger on average, we find that in most cases underwriting fees were increasing in the choice of a foreign underwriter at statistically and economically significant levels after conditioning for issuer characteristics.

We then allow the firms that chose foreign or Japanese underwriters to differ more markedly, using the endogenous switching regressions technique employed by Fang (2005) and Song (2007). Using this methodology, we find that the question of whether foreign or Japanese underwriters are "cheaper" is poorly-posed. Instead, we find that

\footnotetext{
${ }^{1}$ The domestic and euro-yen markets include issues by both Japanese and foreign firms. The Samurai market is a yen-denominated securities market located in Japan that specializes in issues by foreign firms.
} 
firms that chose to issue with Japanese underwriters would be predicted to face higher fees on average by switching to foreign underwriters. The same could also be said for firms issuing with foreign underwriters. In other words, Japanese and foreign underwriters in these markets appear to specialize in servicing specific bond issues in which they enjoy a comparative advantage. ${ }^{2}$

To further investigate the impact of foreign entry into these markets, we turn in the final part of the paper to the liberalization of the Samurai securities market in 1995 that allowed foreign firms to participate in underwriting activities in this market. [Packer and Reynolds (1997)] This deregulation of the Samurai market provides a natural experiment to investigate the impact of allowing access to foreign underwriters. Of course, the Japanese experience of the latter half of the 1990s was anything but tranquil, and other events that could affect the terms of bond issues were also taking place. To control for this, we conduct a matching test of the impact of opening up the Samurai market, using the terms faced by foreign issuers in the euro-yen market as a control. In contrast to the Samurai market, foreign underwriters had been underwriting yendenominated bonds in the euro-yen market since the beginning of the decade. As the Samurai market is limited to foreign issuers as well, our experiment matches foreign issuers in yen-denominated debt in the Samurai market to similar foreign issuers of bonds in the euro-yen market to gauge the implications of the policy change. Our results suggest that opening up the Samurai market to foreign underwriters resulted in a statistically and economically significant reduction in underwriting fees. These results are shown to be

\footnotetext{
2 Note that Carey and Nini (2007) found similar differences between borrower and lender activities by nationality in the syndicated loan market for the U.S. and Europe.
} 
robust to a variety of matching techniques, including variants of Mahalanobis and propensity scoring matching.

The remainder of this paper is divided into seven sections. Section 2 reviews the literature concerning underwriter choice and the determination of underwriter fees. Section 3 discusses our data set. Section 4 examines the determinants of choosing a domestic or foreign underwriter using various regression techniques. Section 5 examines the implications of underwriter choices on fees. Section 6 conducts our difference-indifferences test concerning the liberalization of the Samurai bond market. Section 7 concludes.

\section{Previous Literature}

\subsection{Underwriter Choice and its Implications}

There is a large literature on underwriter reputation and outcomes in equity initial public offerings (IPOs). Carter and Manaster (1990) introduced a model of underwriting services with heterogeneous "prestige" levels for underwriters, measured empirically by revealed hierarchy in the "tombstone announcements" for IPOs. They find that low risk firms choose more prestigious underwriters to reveal their relative safety and avoid underpricing. James (1992) develops a model where underwriters invest in costly information-gathering activities that assist in subsequent underwritings. This implies that underwriters should charge lower spreads to firms that make subsequent issues. These predictions are confirmed in empirical tests of equity IPOs in the United States. Fernando et al. (2005) modeled underwriter choice as a two-sided matching activity. Their model 
predicts that superior underwriters will service more borrowers, but that the market share of less able underwriters will increase as the overall size of the market increases.

For bond underwriting in the U.S., Fang (2005) argued that underwriting firms will specialize among their clientele according to their reputation levels. In particular, higher reputation underwriters are predicted to specialize in underwriting higher-quality firms and charge higher fees than underwriters with lesser reputations. She finds that more reputable underwriters in the U.S. domestic bond market obtained lower bond yields for and charged higher fees to their bond-issuing clients, but the issuer received higher net proceeds overall. She concluded that underwriter reputation generates rents and thus incentives for underwriters to remain reputable.

Another question addressed in the literature is the effect of banking relationships on underwriter choice, and the implications for financial liberalization resulting in entry into underwriting. Kroszner and Rajan (1994) find that banking relationships did not lead to poor decisions in securities underwriting in the United States prior to the imposition of the Glass-Steagall Act in 1933. Following commercial bank entry into bond underwriting in 1989 in the U.S., Yasuda (2005) finds that bank relationships have a positive impact on underwriter choice. Yasuda (2007) finds similar results for the deregulation of the Japanese domestic bond market in 1993 that permitted commercial banks to underwrite corporate bonds.

Overall, however, the bulk of the evidence suggests that liberalization does have a pro-competitive impact, as in Gande, et al (1999) and Kim, et al (2008), who find that commercial bank entry into underwriting services in the U.S. reduced underwriter spreads. 


\subsection{Liberalization of the Japanese bond markets}

The Japanese Ministry of Finance began liberalizing its bond markets during the 1980s. For example, as noted by Nishi and Vergus (2007), foreign firms were first permitted to underwrite euro-yen bonds in 1984. The most far-reaching deregulatory step was the 1992 Financial Institution Reform Act that effectively dismantled the separations between the sectors of the financial industry; i.e., commercial banks, investment banks and insurance firms. For more detailed descriptions, see Hoshi and Kashyap (1999), de Jong et al. (2005), and Yasuda (2007).

The 1992 Act also liberalized access by foreign firms to all three yendenominated bond markets, although there was not an immediate increase in foreign underwriting activity. In fact, the first Samurai bond underwritten by a foreign firm was issued in 1995. As noted in Packer and Reynolds (1997) and Packer (2000), foreign underwriting in the Samurai market was initiated mainly by a 1995 trade agreement between the Japan and the United States; see U.S. Treasury Department (1995).

There is evidence that previous liberalizations in Japanese securities reduced borrowing costs in these markets. McKenzie and Takaoka (2003) found that the 1993 relaxation of the "three bureaus agreement," which had favored the use of Japanese underwriters by firms in the euro-yen bond market, in 1993 (and abolished in 1998) was associated with a reduction in spreads paid in this market. McKenzie and Takaoka 
(2006) found that the 1993 relaxation of restrictions on underwriting activity by Japanese banks reduced spreads in both the euro-yen and domestic Japanese bond markets. ${ }^{3}$

\section{Data}

The dataset we use to examine the yen-denominated bond market consists of 8,459 individual bond issues: 7,854 in the euro-yen market and 605 in the Samurai bond market from 1992 through 2001. The data was obtained from the Capital Data Bondware and Loanware data set from Dealogic. Summary statistics for these bond issues in each market are shown in Table 1. We divide the sample into two time periods, before and after 1996. Note that our switching regression analysis presented in Sections 4 and 5 below only includes the post-1996 portion of our data set, as the first stage regression on underwriter choice would contain no observations with foreign underwriters prior to 1996 in the Samurai market. ${ }^{4}$

Our first variable of interest is JSHARE, which represents the share of Japanese underwriters in the issue as a measure of the degree of domestic participation. This variable ranges from zero to one, with an interior value resulting when an issue has both

\footnotetext{
3 See Lopez and Spiegel (2009) for a discussion of foreign financial intermediation in Japan during the 1990s. There are related studies concerning the impact of foreign competition on the banking sector. Claessens and Glaessner (1998) find that costs of financial services in eight Asian economies were a decreasing function of those countries' financial openness. Peek and Rosengren $(1997,2000)$ document credit supply shocks to Japanese banks operating in the United States as a result of shocks to the parent bank. Goldberg (2006) finds that U.S. bank to loans to Europe are pro-cyclical.

4 Foreign underwriters were legally excluded from that market prior to that date. We do, however, have observations with both foreign and domestic underwriters in the euro-yen market for the earlier period. $* * * *$ Consequently, we provide least squares estimation of the first-stage regressions for the entire sample period for this market in the appendix??? (Table A.1).
} 
foreign and domestic lead managers. ${ }^{5}$ Table 1 shows that average values of JSHARE decreased markedly in both markets over the period from 1996 to 2001. The share of issues with exclusive participation by Japanese underwriters fell from $82 \%$ to $72 \%$ in the euro-yen market, and from $100 \%$ to $78 \%$ in the Samurai market.

LTOTVAL represents the log of total issue value converted from nominal yen value to current nominal dollar values. It can be seen that the average total value of the issues in the Samurai market are largest, and that both markets exhibit a modest decline in average issue size over time. INVGRADE represents the percent of issues rated as "investment grade." The average share of investment grade issues is highest in the euroyen market after 1996, with $96.6 \%$ of issues at investment grade, while the post-1996 Samurai market only has $81.8 \%$ of issues at investment grade. Note that the share of investment grade issues increased in both markets over time.

UNSEASONED is an indicator variable equal to one if the firm is issuing in our sample for the first time in either market. The share of unseasoned issues is lowest for the euro-yen market after 1996, with only 4.1 percent of unseasoned issuers.

UNDREP, our measure of underwriter reputation, is an indicator variable equal to one if the underwriter is among the top ten in that market in that year in terms of total value of issues underwritten. The average share of top underwriters then measures the share of issues in the market underwritten by firms in the market's top ten, which is an indicator of underwriter concentration. Using this measure underwriting activity in the

\footnotetext{
5 Since we do not have data on shares of underwriting fees, we assume that underwriters have the same share of influence over a bond issue; i.e., the share of Japanese underwriters is set at 0.5 when there are two underwriters and one is Japanese.
} 
Samurai market is more concentrated on average after 1996, with a $90 \%$ share, while the top ten underwriters in the euro-yen market only account for a $74 \%$ share.

Similarly, our measure of overall underwriter reputation, OVERUNDREP, is an indicator variable equal to one if the underwriter of an individual issue is among the top ten underwriters across both the euro-yen and Samurai bond markets. Our summary measure in Table 1 is the average of this variable. Concentration is highest in the Samurai market after 1994 at 94 percent, but the euro-yen market is not much lower at a 90 percent share.

Turning to bond characteristics, years-to-maturity of a bond issue tends to be higher in the euro-yen market, averaging 6.8 years before 1996, and growing to 10.2 years after 1996. In contrast, average years to maturity shrank in the Samurai market over the same periods, from 6.5 years to 5.4 years. Note that LYRSMAT or the log of years-tomaturity of the issue is used in the regression analysis. COLLATERAL is an indicator variable for bond issues with explicit collateral requirements. Both the euro-yen and the Samurai market had very few collateralized issues prior to 1996 , less than $1 \%$. However, in the latter portion of our sample, the share of collateralized issues in the euro-yen market rose to $4.6 \%$ while the share in the Samurai market remained below $1 \%$.

We next turn to underwriting fees and yields. FEE is measured as the amount paid to the underwriter divided by the total value of the issue. It can be seen that fees charged in the Samurai market are substantially higher than those charged in the euro-yen market both before and after 1996. In the first subperiod, fees in the Samurai market were about $60 \%$ above those in the euro-yen market $(0.82 \%$ versus $0.53 \%)$. However, in 
the latter subperiod, fees on Samurai issues rose, on average, to $0.95 \%$, while euro-yen fees fell to $0.35 \%$.

Table 2 presents average values for Japanese and foreign or mixed underwriters. We test the statistical significance of these differences with a simple means test. It can be seen that issues with foreign underwriters tend to be larger, more likely to be investment grade, have shorter maturities, and are more likely to be collateralized. Unseasoned issuers are more likely to use foreign underwriters. Since Japanese underwriters are predominant among the leaders in these markets, issues with Japanese underwriters are more likely to be issues with top underwriters, both in the market of issue and overall. Finally, as has been documented elsewhere, issues underwritten by Japanese underwriters have substantially higher fees and spreads.

\section{Determinants of underwriter fees: IV specification}

In this section, we examine the determinants of underwriter fees. We conduct an instrumental variables estimation to address the likely endogeneity of the choice of JSHARE, the share of Japanese participation in underwriting services. Since foreign underwriters were barred from the Samurai market prior to 1996, our sample runs from 1996 through $2001 .^{6}$ As our instrument, we use the nationality of the issuer. As we found in the previous section, Japanese issuers are far more likely to use Japanese underwriters than foreign issuers. We then exclude the nationality of issuer from the specification of the fee equation. This approach implies that after accounting for

\footnotetext{
${ }^{6}$ We include year fixed effects in all specifications. Coefficient estimates on these are suppressed for space, but are available on request.
} 
differences in firm characteristics, the only impact of being a Japanese firm on underwriter fees is through its impact on the choice of underwriter.

Our first-stage results for the regression of JSHARE are reported in Table 3. Looking at the first specification, our measure of firm creditworthiness, INVGRADE, is negative and statistically significant at a 5\% confidence level, indicating that more creditworthy firms are more likely to issue with foreign underwriter participation. The coefficient estimates also indicate economic significance. Our point estimate indicates that the probability of issuing with foreign underwriter participation increases by $6.1 \%$ for investment grade issues. We also obtain a negative and statistically significant coefficient for the total value of issues, LTOTVAL, suggesting that larger issues tend to favor the use of foreign underwriters.

As expected, we obtain a positive and statistically significant coefficient estimate for JAPANISSUER, an indicator variable for Japanese domestic firms. The coefficient is again substantial as well, indicating that Japanese issuers are $6 \%$ more likely, on average, to issue with a Japanese underwriter than non-Japanese firms. We would expect that unseasoned issuers would be more likely to choose foreign underwriters, as they would be less locked into existing relationships with Japanese firms. However, the point estimate for our UNSEASONED variable is not statistically significant, although negative and suggestive that unseasoned issuers are less likely to use foreign underwriters.

The probability of Japanese underwriter participation is also increasing in the log of years to maturity, LYRSMAT. The coefficient estimate also indicates economic significance. A one-standard deviation increase in the log of years to maturity in the full 
sample, which corresponds to a one-year increase, is expected to result in an $11 \%$ increase in the share of Japanese participation. COLLATERAL is insignificant.

Our UNDREP variable enters positively and significantly, with a point estimate that suggests that firms that issue with higher reputation underwriters also are 30.3\% more likely to choose to issue with Japanese underwriters. Finally, our indicator variable for issuance in the Samurai market enters with a positive and statistically significant coefficient. The point estimate suggests that the share of issues with foreign participation is $22 \%$ lower in the Samurai market than in the euro-yen market.

Model 2 includes the OVERUNDREP variable to the Model 1 specification. The results for the previously-included variables are similar, while the OVERUNDREP variable enters significantly positive with a coefficient point estimate that suggests issuers using underwriters with high overall reputations are $30 \%$ more likely to issue with Japanese underwriters. Note that the point estimate for the UNDREP variable decreases markedly when the OVERUNDREP variable is included. This result is not surprising, since these variables are relatively collinear, but the positive coefficient on the UNDREP is robust to the inclusion of the other variable.

Models 3 and 4 introduce the YIELD variable, which measures average nominal yields to maturity, into Models 1 and 2 respectively. ${ }^{7}$ This variable enters positively and significantly in both specifications, indicating that firms that issue paper needing to offer higher yields tend to issue with Japanese underwriters. It can be seen that the coefficients on the prior variables are robust to the introduction of the YIELD variable, with the exception of the collateral variable that becomes positive and significant in contrast to the

\footnotetext{
${ }^{7}$ YIELD can also be interpreted as an additional indicator of the riskiness of the issue, but our primary motivation for its inclusion was to avoid invoking an additional exclusion restriction for this variable as it is introduced in the second stage in Models 3 and 4 below.
} 
results in Table 2. In particular, the INVGRADE variable, which may be an alternative indicator of underlying asset quality, continues to enter negatively at statistically significant levels.

Overall, our first-stage results suggest that Japanese underwriters are favored by firms that are riskier, seasoned and Japanese, and those whose issues are smaller and collateralized. Issuers that are larger, safer and non-Japanese tend to be more likely to choose foreign underwriters in yen-denominated markets.

We next turn to our second stage results concerning the determinants of underwriting fees, adding the instrumented JSHARE as an explanatory variable. As in the previous table, Models 1 and 3 run our specification with only UNDREP included, while Models 2 and 4 include both UNDREP and OVERUNDREP. Moreover, as the cost of issuing debt is also a function of the interest rate paid on debt service, we add the variable YIELD, to our specification in Models 3 and 4 as a check of the robustness of our results. However, we also continue to report our results without this variable, as its inclusion reduces our sample size from 3,540 to 2,462 observations.

Our results are shown in Table 4. Our primary variable of interest is JSHARE, the share of Japanese underwriter participation. It can be seen that this variable enters negatively at statistically significant levels in all of our specifications, indicating that underwriter fees are decreasing in the share of Japanese underwriters after instrumenting for the nationality of the underwriter and conditioning for other issue characteristics. The coefficient point estimates do decrease markedly in absolute value when the YIELD variable is included in Models 3 and 4, from approximately -4 to -0.75 . This result is surprising because it is commonly thought that foreign underwriters competed with 
entrenched Japanese firms on price. Indeed, our summary statistics showed that Japanese underwriters were, on average, more expensive than their foreign competitors. These results suggest that the additional fees levied by Japanese underwriters are more than explained by the characteristics of issues that they service.

Among the other conditioning variables, INVGRADE enters insignificantly throughout, suggesting that asset safety is not priced directly in fees in these markets. We do find that fees are decreasing in LTOTVAL, suggesting economies of scale in the provision of underwriting services. However, this variable becomes insignificant after conditioning for average yields to maturity. LYRSMAT similarly enters positively, but becomes insignificant after conditioning for yields to maturity. COLLATERAL is insignificant throughout. Finally, the SAMURAI variable is both positive and significant, validating the contention that fees are higher in the Samurai market.

Concerning underwriter reputation, both UNDREP and OVERUNDREP enter positively at statistically significant levels, as underwriters with superior reputations can charge higher fees to their issuers. This result may be due to their superior ability to place debt at desirable terms, holding all else equal. Our measure of issuer reputation, UNSEASONED, is insignificant throughout, but enters with a negative point estimate, suggesting that new issuers are able to issue at lower fees. Of course, this does not mean that they are better off, as the increased fees may represent the underwriter's share of the rents associated with a long-term underwriter relationship. Despite these fees, positive rents from this relationship may also accrue to the issuer.

The YIELD variable enters positively and significantly at a $1 \%$ confidence level in Models 3 and 4. This is somewhat surprising, because underwriters would be expected to 
be able to charge higher fees when they achieve yield reductions. It may be the case that YIELD proxies for issue difficulty, as issues with higher risks and probabilities of default may require more diligence and pose a greater threat to the reputation of the underwriter.

After instrumenting for the endogeneity of the issuer nationality decision and other issue characteristics, our primary result is that fees were significantly lower for Japanese underwriters, suggesting that the higher fees charged by Japanese underwriters during this period were more than explained by differences in issuer characteristics.

\section{Endogenous switching regression results}

\subsection{Methodology}

While the analysis above conditions for the influence of the choice of issuer nationality, it constrains the coefficient estimates for the determinants of fees by the other conditioning variables in our specification to be identical across underwriter nationality. This would be problematic if the determinants of underwriting fees differed systematically between Japanese and foreign underwriters. In this section, we allow our second stage coefficient estimates to differ across underwriter nationalities using the endogenous switching regression approach taken by Fang (2005) and Song (2007).

Specifically, we treat the underwriter nationality decision as a binary outcome $I_{i}$, which reflects the share of foreign underwriter participation. The continuous form of this variable, $I_{i}^{*}$ ranges between zero and one, with one reflecting only participation by

foreign underwriters, and zero reflecting only Japanese underwriter participation. $I_{i}^{*}$ is specified to be a function of a set of explanatory variables that satisfies

$$
I_{i}^{*}=z_{i}^{\prime} \gamma+\varepsilon_{i}
$$


where the latent underwriter decision is a function of a set of explanatory variables $Z_{i}$ and an independent and identically distributed error term $\varepsilon_{i}$. We set the discrete realizations

to $I_{i}=1$ for issues that have any foreign underwriter participation, i.e. if $I_{i}^{*}>0$ and $I_{i}=0$ for issues that have all Japanese underwriter participation, i.e. if $I_{i}^{*} \leq 0$.

Our second estimation stage specifies two equations for the determination of bond underwriting fees, one for the foreign underwriters and one for the Japanese underwriters. That is, $y_{f i}=x_{i}{ }^{\prime} \beta_{f}+u_{f i}$ and $y_{j i}=x_{i}{ }^{\prime} \beta_{j}+u_{j i}$, where $y_{f i}$ and $y_{j i}$ are the dependent variables of interest for bond issues underwritten by foreign and Japanese underwriters, respectively. The unobserved (or missing) variables related to underwriter choice are accounted for in this regression by introducing the appropriate Mills-ratio terms generated from our first stage estimation.

\subsection{Results}

Our results are reported in Table 5. The first column represents the first stage regression. Because we separate the samples for the second stage, underwriter nationality is treated as discrete, so that the choice is modeled as between using only Japanese underwriters or having any foreign underwriter participation. It is still the case that the majority of our issues choose only Japanese underwriters.

Overall, our first stage results are quite similar to those that we reported in our IV regressions. As expected, we obtain a positive and statistically significant coefficient estimate for JAPANISSUER, which equals one if the issuing firm is Japanese and zero otherwise. We obtain a negative and significant coefficient for the INVGRADE variable, 
suggesting that Japanese underwriters were less likely to be chosen for these borrowers yen-dominated bond issues.

Turning to issue characteristics, it can be seen that YIELD enters positively and highly significantly. We obtain a negative and statistically significant coefficient for the total value of issues, LTOTVAL, suggesting that smaller issues tend to favor the use of domestic Japanese underwriters. We find that the probability of Japanese underwriter participation is also increasing in the log of years to maturity, LYRSMAT. We find that bonds backed by COLLATERAL are more likely to issue under Japanese underwriters, but the relatively high standard errors on our estimate imply that it is only significant at a $10 \%$ confidence level.

The performances of the remaining variables are all quite similar to the first stage of our IV specification. UNDREP again enters highly positively and significant. The point estimate for our UNSEASONED variable is again positive, but highly insignificant. Finally, our indicator variable for the SAMURAI market is again positive and statistically significant. The point estimate indicates that issues in the Samurai market are $61 \%$ more likely to use Japanese underwriters.

We next turn to our second stage results for the determinants of underwriter fees, which separate issues with purely Japanese underwriters from those with foreign underwriter participation. Here we see wide discrepancies, both with our previous IV results, in which these samples were pooled, and across the two sub-samples.

As in our IV specification, YIELD enters positively and significantly in both subsamples. We would again interpret this result as an increase in YIELD as reflecting a bond that is riskier and harder to place, therefore yielding higher fees. 
As before, we obtain positive coefficient estimates on INVGRADE, although only the Japanese underwriter sub-sample is statistically significant. There may therefore be some evidence of increased fees for riskier placements in the Japanese sub-sample, but we do not find these in the sub-sample of issues with foreign underwriter participation.

The sub-sample of issues with Japanese underwriters also obtains a surprising positive and significant coefficient for LTOTVAL. We had obtained a negative, but insignificant coefficient estimate in our pooled IV specification above. The positive coefficient suggests that there are fewer economies of scale in issuing with Japanese underwriters than we found in our IV specification for the overall sample. In contrast, we obtain a negative but insignificant coefficient for LTOTVAL in the sub-sample with foreign underwriter participation.

We obtain a statistically significant negative coefficient on LYRSMAT for both sub-samples, suggesting that conditional on underwriter nationality it is actually cheaper to place longer-term issues. We also obtain a negative coefficient on COLLATERAL for both sub-samples, again in contrast to the coefficient estimate we obtained for the pooled sample in our IV specification. The estimate is statistically significant at a $5 \%$ confidence level for the sub-sample with only Japanese underwriter participation and at a $10 \%$ confidence level for the sub-sample with some foreign participation. After conditioning for underwriter nationality we find, as expected, that collateralized issues are easier to place, and therefore enjoy access to reduced underwriting fees.

Concerning the remaining variables, UNDREP enters positively as before, and as expected, although only at statistically significant levels for the foreign underwriter subsample. The SAMURAI variable enters positively for both sub-samples, as in the pooled- 
IV specification, although the coefficient enters with an insignificant point estimate for the sub-sample of issues with foreign underwriter participation.

Finally, the constant term estimates provides a measure of average "unexplained" fees in the euro-yen and Samurai markets. As before, we find that after conditioning for issuer characteristics the Japanese underwriters charged lower fees than their foreign counterparts at statistically significant levels.

Our switching regression results differ from our previous pooled-IV specification in a number of dimensions: We obtain a positive coefficient on issue size among firms that issued solely under a Japanese underwriter, as well as negative and statistically significant coefficient estimates on the COLLATERAL variable in both sub-samples.

In addition, a number of our pooled IV results fail to hold with significance for both sub-samples. For example, the coefficient on SAMURAI is insignificant for the subsample of issues with foreign underwriter participation. This likely reflects the fact that firms that choose to use foreign underwriters have more discretion in their choice of markets, so that they would not choose to issue in the Samurai market if doing so resulted in an increase in fees. Similarly, LYRSMAT becomes significantly negative in both subsamples, suggesting that longer-maturity issues, which are likely to extend from safer firms, are more easily placed and hence subject to lower fees.

However, the most surprising new result we find is that fees are increasing in issue size among firms that issued solely under Japanese underwriters. This is not the case for firms issuing with foreign underwriter participation. Foreign underwriters appear to have brought in a number of large global firms desiring to issue yen-denominated paper. Among these firms, one might expect to see some economies of scale, as the fixed 
cost of underwriting could be spread across a larger issue. However, such scale economies do not appear to be present among firms issuing with Japanese underwriters. These firms appear to face a premium in increased fees for larger placements, perhaps because increased issue size among firms using Japanese underwriters was associated with increased default risk during our sample period.

\subsection{Counterfactual Exercise}

As highlighted in Fang (2005) and Song (2007), the endogenous switching regression allows us to generate counterfactual values for our dependent variable. That is, based on the model's estimated parameters, we can infer the fees that the client of a foreign underwriter might have faced if they had used a domestic underwriter. This expected counterfactual value is generated as

$$
\begin{aligned}
& E\left[y_{j i} \mid I_{i}=1\right]=E\left[y_{j i} \mid I_{i}^{*}>0\right] \\
& =E\left[y_{j i} \mid z_{i}{ }^{\prime} \gamma+\varepsilon_{i}>0\right] \\
& =x_{i}{ }^{\prime} \beta_{j}+\operatorname{cov}\left(u_{j i}, \varepsilon_{i}\right)\left[\frac{\phi\left(z_{i}{ }^{\prime} \gamma\right)}{\Phi\left(z_{i}{ }^{\prime} \gamma\right)}\right]
\end{aligned}
$$

where $y_{j i}$ is the fee faced by borrower $i$ who had used a foreign underwriter (i.e., $I_{i}=1$ ) from domestic underwriter $j, x_{i}$ is the borrower's vector of explanatory variables, $\beta_{j}$ is the corresponding parameter vector estimated for Japanese underwriters, and the last term is an adjustment based on the appropriate Mills ratio from the selection equation for foreign underwriters. The expected counterfactual value for a borrower that used a domestic underwriter is 


$$
\begin{aligned}
& E\left[y_{f i} \mid I_{i}=0\right]=E\left[y_{f i} \mid I_{i}^{*} \leq 0\right] \\
& =E\left[y_{f i} \mid z_{i}{ }^{\prime} \gamma+\varepsilon_{i} \leq 0\right] \\
& =x_{i}{ }^{\prime} \beta_{f}+\operatorname{cov}\left(u_{f i}, \varepsilon_{i}\right)\left[\frac{\phi\left(z_{i}^{\prime} \gamma\right)}{1-\Phi\left(z_{i}{ }^{\prime} \gamma\right)}\right]
\end{aligned}
$$

This feature of the modeling framework allows us to examine the differences between the counterfactual and actual values of the dependent variable of interest. In notation, the price improvement term for a borrower using a Japanese underwriter is expressed as $d_{j i}=E\left[y_{j i} \mid I_{i}=0\right]-y_{j i}$, and the term for a borrower using a foreign underwriter is $d_{f i}=E\left[y_{f i} \mid I_{i}=1\right]-y_{f i}$. In our analysis, we examine the average values of these differences to determine whether and how these price improvement terms are statistically significant. We examine these averages over the full sample of issues broken out by the type of underwriter actually used. We extend the analysis by subdividing these groups by issuer nationality, seasoned borrowers and underwriter reputation.

Table 6 presents the results of our counterfactual analysis for the Samurai and euro-yen markets. We compare the fees paid with those that our model suggests would have been attainable by switching from a foreign underwriter to a Japanese one, or vice versa. The first row shows the actual fees paid by firms in our sample that chose foreign underwriters and the hypothetical fees that our model predicts they would have paid if they issued with Japanese underwriters. Our results indicate that firms issuing under foreign underwriters paid an average of 50.9 basis points in fees (i.e., the ratio of gross fees on a bond underwriting to total issuance amount), while they would have paid an average of 63.6 basis points had they chosen Japanese underwriters, achieving a statistically significant savings of 12.7 basis points. We also find that firms choosing 
Japanese underwriters saved on fees relative to the fees that they would have faced from foreign underwriters. The estimated savings on fees by these firms was again substantial, 18.5 basis points, again significant at a $1 \%$ confidence level.

To examine these aggregate results further, we subdivided the full sample in three ways: by issuer nationality, by underwriter reputation, and by seasoned borrowers. In all cases, borrowers appear to have made the "correct" choice, in that they would have faced higher underwriting fees by issuing under the alternative group of underwriters. Moreover, in all cases but one, the discrepancy is statistically significant at a $1 \%$ confidence level. The lone exception is the group of seasoned issuers that issue under Japanese underwriters. We obtain a positive, but insignificant estimate of the savings in fees enjoyed by this group relative to what they would have been predicted to face had they issued with foreign underwriters of a paltry 1.4 basis points. This suggests that Japanese underwriters did not price their services aggressively in efforts to attract new

clients, which are well-represented by our sample of unseasoned borrowers. This may in part explain their declining market share over the latter half of the 1990s.

\section{6. "Big Bang” Deregulation in the Samurai Market}

The relative fees of foreign and Japanese underwriters do not imply anything about the competitive impact of foreign competition in yen-denominated bond markets. Even if foreign underwriters charge higher fees, they may provide superior services or serve specific segments of the market, as our counterfactual results suggested in the previous section, such that their presence still provides competitive pressure to domestic 
underwriters. To answer the question of the impact of foreign entry, we examine the 1996 "Big Bang" deregulation in the Japanese Samurai market.

As shown in Figure 1, prior to the fall of 1995 not a single foreign underwriter had participated in this market. ${ }^{8}$ However, the share of participation by foreign underwriters grew rapidly after the 1996 liberalization, culminating in 2000. After that year, the low interest rates associated with the quantitative easing program adopted by the Bank of Japan reduced the relative attractiveness of the Japanese bond market to foreign investment banks and their market shares declined.

This section examines the impact of the Samurai market liberalization on competitive conditions faced by foreign issuers in that market, taking 1996 as the break year for the liberalization. We use propensity scoring matching, with foreign issues in the euro-yen bond market as a control. For quality matching to take place, it must be the case that there are substantial overlaps in the types of firms issuing in the two samples and that there is sufficient data on firm characteristics that allows us to identify good matches. In our case, both of these should apply. We have an ample number of yen-denominated issues in the euro-yen market from which to choose matches, as the number of euro-yen issues far exceeds the number of issues in the Samurai market.

Figure 2 reveals that underwriting fees in the Samurai market followed an interesting path over the course of our sample. Underwriter fees in the Samurai market were notably higher than those in the euro-yen market from 1996 through 1998, and then fell dramatically to almost equal the euro-yen fee levels.

\footnotetext{
${ }^{8}$ The two issues in the fall of 1995 were both underwritten by Merrill Lynch, which underwrote one of its own issues as well as an issue by Volvo Group Finance. These 2 issues accounted for only $2.46 \%$ of Samurai issues that year.
} 
We therefore proceed by matching our observations from the Samurai market with control issues from the euro-yen market using matching methods to account for changes in the characteristics of issues in the two markets. ${ }^{9}$ To examine the robustness of our results, we use two alternative matching mechanisms:

First, we use the Mahalanobis matching method, which matches treatment observations with their counterparts in the untreated group with the closest characteristics. Given an observation in the treated group with characteristics $X_{i}$, the Mahalanobis distance from an observation in the control group with characteristics $X_{j}$, $m d\left(X_{i}, X_{j}\right)$, satisfies

$$
m d\left(X_{i}, X_{j}\right)=\left\{\left(X_{i}-X_{j}\right)^{\prime} S^{-1}\left(X_{i}-X_{j}\right)\right\}^{\frac{1}{2}}
$$

where $S$ is the sample covariance of $X$.

Our characteristic vector includes the same conditioning variables as those used in the second stage of our IV specification. In particular, we use JSHARE, our continuous indicator of the share of Japanese underwriter participation, rather than the discrete classification we were forced to use in the previous section for our switching regression analysis, as it is more informative for issues with mixed participation. We also include time dummies. As a robustness check, we repeat the exercise and tighten the calipers, effectively eliminating treated observation outliers that do not have corresponding matches in the untreated group with sufficiently similar characteristics.

\footnotetext{
${ }^{9}$ One potential problem with our controls might arise if the Samurai and euro-yen markets differ in their credit rating standards. Packer and Reynolds (1997) find that Japanese agencies tend to give higher ratings than their US counterparts, but the magnitude of this discrepancy appears to be similar in the Samurai and domestic Japanese securities markets.
} 
Second, we also match using propensity scores. This method matches each treated observation with one or more untreated observations that have sufficiently close probabilities of being in the treated group. This is done in a two-step procedure, where we initially run a Probit regression to estimate each observation's propensity score and then use these estimated propensity scores to match our treated observations and estimate the impact of the treatment. The conditioning variables used in our Probit estimation are the same as those above, except SAMURAI, COLLATERAL, and the time dummies needed to be dropped, as they predicted success or failure perfectly. Again, as a robustness check for the propensity scoring estimates, we match each treated observation both to its "nearest neighbor" in the untreated group, as well as a wider set of neighbors, set to the nearest 10 neighbors in our reported results below.

Note that we are comparing the impact of allowing foreign underwriter entry in the Samurai market to activity in the euro-yen market, which allowed foreign entry over the duration of our sample. Consequently, our matching exercise will yield an estimate of the impact of not allowing foreign entry in the Samurai market, rather than of allowing entry. However, this should still provide a consistent estimate of the impact of the liberalization in the Samurai market.

Our results are reported in Table 7. It can be seen that regardless of the matching method chosen, we find that there was a statistically significant average treatment on the treated (ATT) at standard confidence levels, although the statistical significance fell to a $10 \%$ level using the propensity scoring method. The average effect over our four matching methods was equal to 23.4 basis points. Our test therefore indicates that after controlling for issue characteristics, the decline in fees was significantly larger for the 
treatment group (foreign yen-denominated issuers in the Samurai market) than for the control group (foreign yen-denominated issuers in the euro-yen market). The results therefore indicate that the 1996 liberalization that allowed foreign banks to offer underwriting services in the Samurai bond market led to reduced fees in that market. ${ }^{10}$

Because the policy intervention concerns the allowance of foreign underwriter participation, we cannot condition on the choice of underwriter prior to 1996 . This poses a potential problem for our specification, as we verified above that the choice of underwriter nationality is endogenous to firm characteristics. We therefore provide some robustness analysis by examining the impact of the policy liberalization on the subset of firms that issued under domestic Japanese underwriters. We do this for the same set of conditioning variables in the lower part of Table 7. It can be seen that our results are robust to isolating this sub-sample, as the advent of foreign underwriters is shown to have resulted in a statistically significant decrease in expected fees in four out of the five exercises. The lone exception is the one-to-one propensity scoring specification, which displays a drop in expected fees, but one that is statistically insignificant.

\section{Conclusion}

This paper examines the impact of foreign participation in underwriting services on Japanese bond markets. We first looked at the determinants and implications of the use of foreign underwriters in the euro-yen and Samurai bond markets. There were

\footnotetext{
${ }^{10} \mathrm{We}$ also conducted a number of robustness tests. First, we ran both Mahalonobis matching and one-toone propensity scoring matching with interest rate spreads included. These specifications also indicated that there was a substantial decrease in fees. However, the small sample size resulted in large estimated standard errors, as there were only 16 treated observations meeting our support criteria. Second, we introduced the share of foreign underwriters as an additional conditioning variable and obtained similar statistically significant results as those reported in the text.
} 
notable differences between issues that chose domestic or foreign underwriters. Japanese underwriters are favored by firms that are riskier, seasoned and Japanese, and those with bond issues that are smaller and collateralized. Issuers that are larger, safer and nonJapanese tend to be more likely to choose foreign underwriters in yen-denominated markets. Indeed, while Japanese underwriters were found to charge higher fees on average than their foreign counterparts, we found that after conditioning for issue characteristics and instrumenting for the underwriter nationality decision, Japanese underwriting fees were actually below those of their foreign counterparts.

Still, our results did not necessarily imply that Japanese underwriters were "cheaper," as it is possible that Japanese and foreign underwriters specialized in servicing different types of issuers. Our switching regression results confirmed this possibility, as neither firms that issued with Japanese or foreign underwriters appear to have made an error in their underwriter nationality choice. Instead, our counterfactual analysis predicted that both groups would have faced higher fees had they underwriter nationality.

Finally, we examine the impact of entry by foreign underwriters in the Japanese bond market, using the test case of the 1996 liberalization of foreign participation in the Japanese Samurai bond market. We conducted a Mahalonobis and propensity scoring matching exercise, using foreign yen-denominated issues in the euro-yen market as a control. Our results provided robust evidence that spreads in the euro-yen market fell after the liberalization.

Overall, then, our results indicate that there is partial segmentation of the issuer markets served by Japanese and foreign underwriters. On one hand, we find some evidence of segmentation, as both firms issuing with Japanese and foreign underwriters 
appear to have received lower fees than they would have obtained by switching underwriter nationality. However, we also found that allowing entry by foreign underwriters in the Samurai bond market appeared to lead to a statistically significant reduction in underwriting fees, even for the sub-sample of firms that solely issued with Japanese underwriters. This finding suggests that foreign and Japanese underwriters are partly in competition with each other as well, so that the segmentation is incomplete. 


\section{References}

Carter, R. and Manaster, S., 1990. "Initial Public Offerings and Underwriter Reputation, Journal of Finance, 45, 1045-1067.

Carey, M. and Nini, G., 2007. "Is the Corporate Loan Market Globally Integrated? A Pricing Puzzle," Journal of Finance, 62, 2969-3007.

Claessens, S. and Glaessner, T., 1998. "Internationalization of Financial Services in Asia," Policy Research Working Paper \#1911, World Bank.

de Jong, A., Roosenboum, P. and Schramade, W., 2005. "Bond Underwriting Fees and Keiretsu Affiliation in Japan," Manuscript, Rotterdam School of Management, Erasmus University.

Fang, L.H., 2005. "Investment Bank Reputation and the Price and Quality of Underwriting Services,” Journal of Finance, 60, 2729-2761.

Fernando, C.S., Gatchev, V.A. and Spindt, P.A., 2005. "Wanna Dance? How Firms and Underwriters Choose Each Other, Journal of Finance, 60, $2437-2468$.

Gande, Amar, Manju Puri, and Anthony Saunders, 1999, "Bank Entry, Competition, and the Market for Corporate Securities Underwriting," Journal of Financial Economics, 54, 165-195.

Goldberg, L, 2006. "The International Exposure of U.S. Banks: Europe and Latin America Compared," in Edwards, S., ed. Capital Controls and Capital Flows in Emerging Economies: Policies, Practices and Consequences. NBER and University of Chicago Press, forthcoming.

Hoshi, Takeo and Anil K. Kashyap, 2001, Corporate Financing and Governance in Japan, MIT Press, Cambridge, Massachusetts.

James, Christopher, 1992, "Relationship-Specific Assets and the Pricing of Underwriter Services, Journal of Finance, 47(5), 1865-1885.

Kim, Dongcheol, Darius Palia, and Anthony Saunders, 2008, "The Impact of Commercial Banks on Underwriting Spreads: Evidence from Three Decades," Journal of Financial and Quantitative Analysis, 43(4), 975-1000.

Kroszner, Randall S. and Raghuram G. Rajan, 1994, "Is the Glass-Steagall Act Justified? A Study of the U.S. Experience with Universal Banking Before 1933," American Economic Review, 84(4), 810-832. 
Lopez, Jose A. and Mark M. Spiegel, 2009. "Foreign Intermediation in Japan during the Lost Decade," in Cheung, Y.W. and Wong, K.Y. (eds.) China and Asia:

Economic and Financial Interactions. London: Routledge Press. Pages 195-214.

McKenzie, C.R. and Sumiko Takaoka, 2003, "The Impact of Japanese Deregulation on the Euro-Yen Bond Market," in D.A. Post, ed., MODSIM 2003 International Congress on Modeling and Simulation Proceedings, vol. 3: Socio-Economic Systems, Modeling and Simulation Society of Australia and New Zealand, Townsville, 1463-1468.

McKenzie, C.R. and Sumiko Takaoka, 2006, "The Impact of Bank entry in the Japanese Corporate Bond Market," Journal of Banking and Finance, 30, 59-83.

Nishi, Fumiaki and Alexander Vergas, 2007, “Asian Bond Issues in Tokyo: History, Structure and Prospects," BIS Papers, no. 30, 143-167.

Packer, F., 2000. "Credit Ratings and Spreads in the Samurai Bond Market," in Aoki, M. and Saxonhouse, G.R., eds. Finance, Governance and Competitiveness in Japan. Oxford: Oxford University Press.

Packer, Frank and Elizabeth Reynolds, 1997, "The Samurai bond Market," Current Issues in Economics and Finance, 3(8), June, 1-6.

Peek, J. and Rosengren, E.S., 1997. "The International Transmission of Financial Shocks: The Case of Japan," American Economic Review, 87, 495-505.

Peek, J. and Rosengren, E.S., 2000. "Collateral Damage: Effects of the Japanese Bank Crisis on Real Activity in the United States," American Economic Review, 90, 3045.

Pohl, Nicole, 2002, “Foreign Penetration of Japan's Investment Banking Market: Will Japan Experience the Wimbledon Effect?,” APARC Research Paper, Stanford University.

Song, W.L., 2007. "Why Do Some Firms Make Seemingly Inferior Decisions?," Manuscript, Louisiana State University.

U.S. Treasury Department, 1995. "Measures by the Government of Japan and the Government of the U.S. Regarding Financial Services," Joint Statement by the Government of Japan and the Government of the United States, February 13.

Yasuda, A., 2005. "Do Bank Relationships Affect the Firm's Underwriter Choice in the Corporate-Bond Market?," Journal of Finance, 60, 1259-1292.

Yasuda, A., 2007. "Bank Relationships and Underwrite Competition: Evidence from Japan,” Journal of Financial Economics, 86, 369-404. 
Table 1

Summary statistics

\begin{tabular}{|l|c|c|c|c|}
\hline & \multicolumn{2}{|c|}{ Euro-yen Market } & \multicolumn{2}{c|}{ Samurai Market } \\
\hline & Year $<1996$ & Year $\geq 1996$ & Year $<1996$ & Year $\geq 1996$ \\
\hline Avg. log of total value of issue & 17.65 & 16.71 & 19.17 & 19.10 \\
\hline \% investment grade & 82.59 & 96.64 & 67.73 & 81.82 \\
\hline Avg. years to maturity & 6.76 & 10.15 & 6.55 & 5.38 \\
\hline$\%$ issuer first time & 14.96 & 4.27 & 30.91 & 8.31 \\
\hline Avg. share of top underwriters & 0.74 & 0.74 & 0.81 & 0.90 \\
\hline $\begin{array}{l}\text { Avg. overall share of top } \\
\text { underwriters }\end{array}$ & 0.75 & 0.87 & 0.83 & 0.93 \\
\hline$\%$ collateralized & 0.68 & 4.63 & 0.45 & 0 \\
\hline Avg. fee & 0.53 & 0.35 & 0.82 & 0.95 \\
\hline Avg. yield & 3.37 & 2.43 & 5.09 & 3.93 \\
\hline $\begin{array}{l}\text { Avg. Japanese underwriter share } \\
\text { (\%) }\end{array}$ & 0.82 & 0.72 & 0.99 & 0.78 \\
\hline \# of issues & 2,045 & 5,809 & 220 & 385 \\
\hline
\end{tabular}

Note: Monetary values are in current U.S. dollars. 
Table 2

Domestic vs. foreign or mixed underwriters of Samuarii and euroyen bonds 1996-2001

\begin{tabular}{|c|c|c|c|}
\hline & $\begin{array}{c}\text { Domestic } \\
\text { underwriters }\end{array}$ & $\begin{array}{l}\text { Foreign or mixed } \\
\text { underwriters }\end{array}$ & Difference \\
\hline Log of total value & $\begin{array}{c}16.6 \\
(0.02) \\
\end{array}$ & $\begin{array}{c}17.4 \\
(0.03) \\
\end{array}$ & $\begin{array}{c}-0.78 * * * \\
(0.04)\end{array}$ \\
\hline Investment grade & $\begin{array}{c}0.95 \\
(0.003) \\
\end{array}$ & $\begin{array}{c}0.97 \\
(0.004) \\
\end{array}$ & $\begin{array}{c}-0.02 * * * \\
(0.005)\end{array}$ \\
\hline Years to maturity & $\begin{array}{c}11.3 \\
(0.14) \\
\end{array}$ & $\begin{array}{c}6.2 \\
(0.18) \\
\end{array}$ & $\begin{array}{c}5.14 * * * \\
(0.22)\end{array}$ \\
\hline Issuer first time & $\begin{array}{c}0.03 \\
(0.003) \\
\end{array}$ & $\begin{array}{c}0.07 \\
(0.006) \\
\end{array}$ & $\begin{array}{c}-0.04 * * * \\
(0.007) \\
\end{array}$ \\
\hline Collateralized & $\begin{array}{c}0.03 \\
(0.003) \\
\end{array}$ & $\begin{array}{c}0.07 \\
(0.006)\end{array}$ & $\begin{array}{c}-0.03 * * * \\
(0.006)\end{array}$ \\
\hline Underwriter reputation & $\begin{array}{c}0.80 \\
(0.006)\end{array}$ & $\begin{array}{c}0.61 \\
(0.01)\end{array}$ & $\begin{array}{c}0.19 * * * \\
(0.01)\end{array}$ \\
\hline Overall underwriter reputation & $\begin{array}{c}0.97 \\
(0.003)\end{array}$ & $\begin{array}{c}0.75 \\
(0.01)\end{array}$ & $\begin{array}{c}0.22 * * * \\
(0.01)\end{array}$ \\
\hline Fee & $\begin{array}{c}0.45 \\
(0.009)\end{array}$ & $\begin{array}{c}0.27 \\
(0.01)\end{array}$ & $\begin{array}{c}0.18 * * * \\
(0.02)\end{array}$ \\
\hline Yield & $\begin{array}{c}2.93 \\
(0.03)\end{array}$ & $\begin{array}{c}1.72 \\
(0.05)\end{array}$ & $\begin{array}{c}1.22 * * * \\
(0.06)\end{array}$ \\
\hline Japanese underwriter share & $\begin{array}{c}1.0 \\
(0.0) \\
\end{array}$ & $\begin{array}{c}0.02 \\
(0.003)\end{array}$ & $\begin{array}{l}0.98 * * * \\
(0.003)\end{array}$ \\
\hline \# of issues & 4412 & 1782 & -- \\
\hline
\end{tabular}

Note: This table summarizes our database of issuance in the yen-denominated Samurai and euroyen bond markets, but excludes data on issuance in the Japanese domestic bond market. Standard errors are reported in parentheses. * denotes significance at the $10 \%$ level; ** denotes significance at the 5\% level; and *** denotes significance at the $1 \%$ level. 
Table 3

Determinants of Underwriter Nationality

Dependent variable: Share of Japanese underwriters

Estimation technique: OLS regression

\begin{tabular}{|c|c|c|c|c|}
\hline & (1) & $(2)$ & (3) & $(4)$ \\
\hline \multirow[t]{2}{*}{ CONSTANT } & $1.54 * * *$ & $1.44 * * *$ & $1.22 * * *$ & $1.14 * * *$ \\
\hline & $(0.11)$ & $(0.11)$ & $(0.12)$ & $(0.12)$ \\
\hline \multirow[t]{2}{*}{ JAPANISSUER } & $0.060 * * *$ & $0.056 * * *$ & $0.14 * * *$ & $0.14 * * *$ \\
\hline & $(0.015)$ & $(0.015)$ & $(0.020)$ & $(0.020)$ \\
\hline \multirow[t]{2}{*}{ YIELD } & & & $0.035 * * *$ & $0.035 * * *$ \\
\hline & & & $(0.0078)$ & $(0.0078)$ \\
\hline \multirow[t]{2}{*}{ INVGRADE } & $-0.061 * * *$ & $-0.064 * * *$ & $-0.061 * *$ & $-0.064 * * *$ \\
\hline & $(0.024)$ & $(0.023)$ & $(0.025)$ & $(0.024)$ \\
\hline \multirow[t]{2}{*}{ LTOTVAL } & $-0.066 * * *$ & $-0.064 * * *$ & $-0.054 * * *$ & $-0.053 * * *$ \\
\hline & $(0.0054)$ & $(0.0054)$ & $(0.0061)$ & $(0.0061)$ \\
\hline \multirow[t]{2}{*}{ LYRSMAT } & $0.11 * * *$ & $0.11 * * *$ & $0.12 * * *$ & $0.11 * * *$ \\
\hline & $(0.0086)$ & $(0.0086)$ & $(0.011)$ & $(0.011)$ \\
\hline \multirow[t]{2}{*}{ COLLATERAL } & 0.035 & 0.031 & $0.080 *$ & $0.074 *$ \\
\hline & $(0.039)$ & $(0.039)$ & $(0.044)$ & $(0.043)$ \\
\hline \multirow[t]{2}{*}{ UNDREP } & $0.30 * * *$ & $0.083^{*}$ & $0.27 * * *$ & 0.070 \\
\hline & $(0.027)$ & $(0.048)$ & $(0.028)$ & $(0.053)$ \\
\hline \multirow[t]{2}{*}{ OVERUNDREP } & & $0.29 * * *$ & & $0.26 * * *$ \\
\hline & & $(0.054)$ & & $(0.060)$ \\
\hline \multirow[t]{2}{*}{ UNSEASONED } & -0.013 & -0.023 & 0.011 & 0.0042 \\
\hline & $(0.032)$ & $(0.031)$ & $(0.032)$ & $(0.031)$ \\
\hline \multirow[t]{2}{*}{ SAMURAI } & $0.22 * * *$ & $0.21 * * *$ & $0.17 * * *$ & $0.17 * * *$ \\
\hline & $(0.025)$ & $(0.025)$ & $(0.027)$ & $(0.027)$ \\
\hline No. Obs. & 3069 & 3069 & 2462 & 2462 \\
\hline $\mathrm{R}^{2}$ & 0.29 & 0.30 & 0.31 & 0.32 \\
\hline
\end{tabular}

Note: Ordinary least squares regression of determinant of share of Japanese underwriters, with robust standard errors in parentheses. Year dummies have been estimated, but are not reported.

Standard errors are reported in parentheses. * denotes significance at the $10 \%$ level; ** denotes significance at the $5 \%$ level; and *** denotes significance at the $1 \%$ level. 
Table 4

Determinants of Underwriting Fees

Dependent variable: Underwriter fees/total values of issue (\%)

Estimation technique: IV regression

\begin{tabular}{|c|c|c|c|c|}
\hline & (1) & (2) & (3) & (4) \\
\hline \multirow[t]{2}{*}{ CONSTANT } & $6.12 * * *$ & $6.05 * * *$ & 0.72 & 0.68 \\
\hline & $(1.80)$ & $(1.87)$ & $(0.49)$ & $(0.48)$ \\
\hline \multirow[t]{2}{*}{ JSHARE } & $-3.93 * * *$ & $-4.17 * * *$ & $-0.75 * *$ & $-0.76 * *$ \\
\hline & $(1.05)$ & (1.17) & $(0.30)$ & $(0.30)$ \\
\hline \multirow[t]{2}{*}{ YIELD } & & & $0.14 * * *$ & $0.14 * * *$ \\
\hline & & & $(0.019)$ & $(0.019)$ \\
\hline \multirow[t]{2}{*}{ INVGRADE } & -0.18 & -0.20 & 0.032 & 0.029 \\
\hline & $(0.13)$ & $(0.14)$ & $(0.044)$ & $(0.045)$ \\
\hline \multirow[t]{2}{*}{ LTOTVAL } & $-0.23 * * *$ & $-0.24 * * *$ & -0.016 & -0.016 \\
\hline & $(0.076)$ & $(0.082)$ & $(0.019)$ & $(0.019)$ \\
\hline \multirow[t]{2}{*}{ LYRSMAT } & $0.39 * * *$ & $0.41 * * *$ & -0.055 & -0.055 \\
\hline & $(0.11)$ & $(0.12)$ & $(0.048)$ & $(0.048)$ \\
\hline \multirow[t]{2}{*}{ COLLATERAL } & 0.083 & 0.073 & 0.0086 & 0.0055 \\
\hline & $(0.16)$ & $(0.17)$ & $(0.067)$ & $(0.066)$ \\
\hline \multirow[t]{2}{*}{ UNDREP } & $1.28 * * *$ & $0.41 *$ & $0.29 * * *$ & $0.16 * * *$ \\
\hline & $(0.34)$ & $(0.22)$ & $(0.087)$ & $(0.053)$ \\
\hline \multirow[t]{2}{*}{ OVERUNDREP } & & $1.26 * * *$ & & $0.18 *$ \\
\hline & & $(0.41)$ & & $(0.10)$ \\
\hline \multirow[t]{2}{*}{ UNSEASONED } & -0.11 & -0.16 & -0.0028 & -0.0075 \\
\hline & $(0.14)$ & $(0.15)$ & $(0.048)$ & $(0.048)$ \\
\hline \multirow[t]{2}{*}{ SAMURAI } & $1.27 * * *$ & $1.29 * * *$ & $0.41 * * *$ & $0.41 * * *$ \\
\hline & $(0.22)$ & $(0.23)$ & $(0.082)$ & $(0.081)$ \\
\hline No. Obs. & 3069 & 3069 & 2462 & 2462 \\
\hline $\mathrm{R}^{2}$ & - & . & 0.084 & 0.076 \\
\hline
\end{tabular}

Note: IV estimation of underwriter fees, with robust standard errors in parentheses. Year dummies have been estimated, but are not reported.

Standard errors are reported in parentheses. * denotes significance at the $10 \%$ level; ** denotes significance at the $5 \%$ level; and *** denotes significance at the $1 \%$ level. 
Table 5

Endogenous Switching Regression Results

for Fees on Euroyen and Samurai Bonds after 1995

\begin{tabular}{|c|c|c|c|}
\hline & $\begin{array}{l}\text { Pr(Japanese } \\
\text { underwriter) }\end{array}$ & $\begin{array}{l}\text { Fees charged } \\
\text { by Japanese } \\
\text { underwriters }\end{array}$ & $\begin{array}{l}\text { Fees charged } \\
\text { by foreign } \\
\text { underwriters }\end{array}$ \\
\hline \multirow[t]{2}{*}{ CONSTANT } & $3.72 * * *$ & $-0.74 * * *$ & 0.049 \\
\hline & $(0.51)$ & $(0.13)$ & $(0.25)$ \\
\hline \multirow[t]{2}{*}{ JAPANISSUER } & $0.55 * * *$ & & \\
\hline & $(0.088)$ & & \\
\hline \multirow[t]{2}{*}{ YIELD } & $0.18 * * *$ & $0.092 * * *$ & $0.22 * * *$ \\
\hline & $(0.021)$ & $(0.0043)$ & $(0.0089)$ \\
\hline \multirow[t]{2}{*}{ INVGRADE } & $-0.30 * *$ & $0.17 * * *$ & 0.030 \\
\hline & $(0.15)$ & $(0.031)$ & $(0.062)$ \\
\hline \multirow[t]{2}{*}{ LTOTVAL } & $-0.27 * * *$ & $0.056 * * *$ & -0.0062 \\
\hline & $(0.026)$ & $(0.0074)$ & $(0.014)$ \\
\hline \multirow[t]{2}{*}{ LYRSMAT } & $0.46 * * *$ & $-0.16 * * *$ & $-0.10 * * *$ \\
\hline & $(0.045)$ & $(0.012)$ & $(0.020)$ \\
\hline \multirow[t]{2}{*}{ COLLATERAL } & $0.28 *$ & $-0.093 * *$ & $-0.10 *$ \\
\hline & $(0.17)$ & $(0.045)$ & $(0.059)$ \\
\hline \multirow[t]{2}{*}{ UNDREP } & $0.87 * * *$ & 0.044 & $0.076 * *$ \\
\hline & $(0.096)$ & $(0.034)$ & $(0.034)$ \\
\hline \multirow[t]{2}{*}{ UNSEASONED } & 0.095 & 0.0049 & 0.0034 \\
\hline & $(0.14)$ & $(0.038)$ & $(0.044)$ \\
\hline \multirow[t]{2}{*}{ SAMURAI } & $0.61 * * *$ & $0.35 * * *$ & 0.050 \\
\hline & $(0.12)$ & $(0.029)$ & $(0.042)$ \\
\hline $\mathrm{N}$ & & & 2462 \\
\hline
\end{tabular}

Note: Endogenous switching regression of underwriting fees in the euroyean and Samuarii bond markets. Year dummies have been estimated, but are not reported. Standard errors are reported in parentheses. * denotes significance at the $10 \%$ level; ** denotes significance at the 5\% level; and *** denotes significance at the $1 \%$ level. 
Table 6

Counterfactual analysis of underwriting fees in the Samurai and euroyen bond markets

\begin{tabular}{|c|c|c|c|c|}
\hline & & \multicolumn{3}{|c|}{$\begin{array}{c}\text { Fees } \\
\text { (in basis points) }\end{array}$} \\
\hline $\begin{array}{c}\text { Borrower } \\
\text { type }\end{array}$ & $\begin{array}{c}\text { Underwriter } \\
\text { nationality }\end{array}$ & Actual & $\begin{array}{l}\text { Counter- } \\
\text { factual }\end{array}$ & Difference \\
\hline \multirow[t]{2}{*}{ All } & Foreign & 50.935 & 63.632 & $12.696 * * *$ \\
\hline & Japanese & 38.089 & 56.575 & $18.485 * * *$ \\
\hline \multirow[t]{2}{*}{ Japanese } & Foreign & 29.214 & 39.942 & $10.727 * * *$ \\
\hline & Japanese & 18.992 & 40.504 & $21.512 * * *$ \\
\hline \multirow[t]{2}{*}{ Foreign } & Foreign & 62.918 & 76.700 & $13.782 * * *$ \\
\hline & Japanese & 42.014 & 59.877 & $17.863 * * *$ \\
\hline \multirow[t]{2}{*}{ Seasoned } & Foreign & 50.362 & 63.590 & $13.228 * * *$ \\
\hline & Japanese & 38.884 & 57.011 & $18.127 * * *$ \\
\hline \multirow[t]{2}{*}{ Unseasoned } & Foreign & 63.138 & 64.526 & 1.388 \\
\hline & Japanese & 28.119 & 51.101 & $22.982 * * *$ \\
\hline \multirow{2}{*}{$\begin{array}{l}\text { Low } \\
\text { reputation } \\
\text { underwriter }\end{array}$} & Foreign & 47.827 & 61.117 & $13.290 * * *$ \\
\hline & Japanese & 35.837 & 54.650 & $18.813 * * *$ \\
\hline \multirow{2}{*}{$\begin{array}{l}\text { High } \\
\text { reputation } \\
\text { underwriter }\end{array}$} & Foreign & 51.140 & 63.797 & $12.657 * * *$ \\
\hline & Japanese & 38.948 & 57.308 & $18.360 * * *$ \\
\hline
\end{tabular}

Note: Counterfactual analysis of underwriting fees in the Samurai and euroyen bond markets based on endogenous switching regression techniques.

$*$ denotes significance at the $10 \%$ level; $* *$ denotes significance at the $5 \%$ level; and $* * *$ denotes significance at the $1 \%$ level. 
Table 7

Impact of liberalization in Samurai market

Dependent Variable: Underwriting fees

\begin{tabular}{|l|c|c|c|c|c|}
\hline & Unmatched & $\begin{array}{c}\text { Mahalanobis } \\
\text { match }\end{array}$ & $\begin{array}{c}\text { Mahalanobis } \\
\text { match } \\
\text { Reduced } \\
\text { caliper }\end{array}$ & $\begin{array}{c}\text { Propensity } \\
\text { scoring } \\
\text { one-to-one }\end{array}$ & $\begin{array}{c}\text { Propensity } \\
\text { scoring } \\
\text { Nearest } \\
\text { neighbor }\end{array}$ \\
\hline Treated & 0.82 & 0.82 & 0.86 & 0.82 & 0.82 \\
\hline Controls & 0.52 & 0.50 & 0.48 & 0.72 & 0.75 \\
\hline Difference & $0.30 * * *$ & $0.32 * * *$ & $0.38 * * *$ & $0.10 *$ & $0.07 *$ \\
\hline S.E. & 0.03 & 0.09 & 0.10 & 0.06 & 0.04 \\
\hline T-stat & 8.77 & 3.65 & 3.81 & 1.79 & 1.68 \\
\hline Untreated & 2190 & 2190 & 2190 & 2190 & 2190 \\
\hline Treated & 211 & 211 & 188 & 211 & 211 \\
\hline
\end{tabular}

Note: Difference-in-differences matching exercise.

* denotes significance at the $10 \%$ level; ** denotes significance at the $5 \%$ level; and *** denotes significance at the $1 \%$ level. 
Figure 1

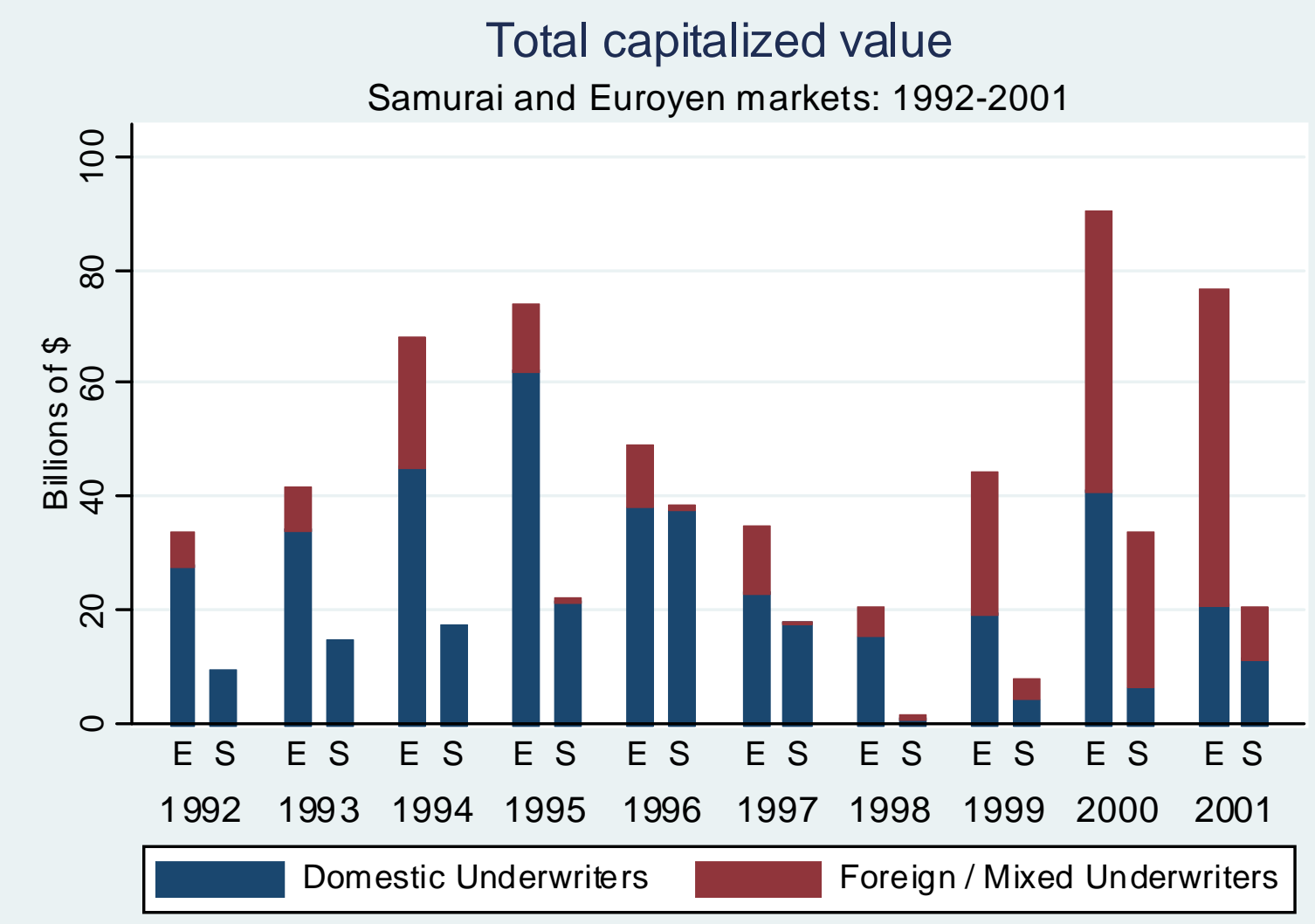


Figure 2

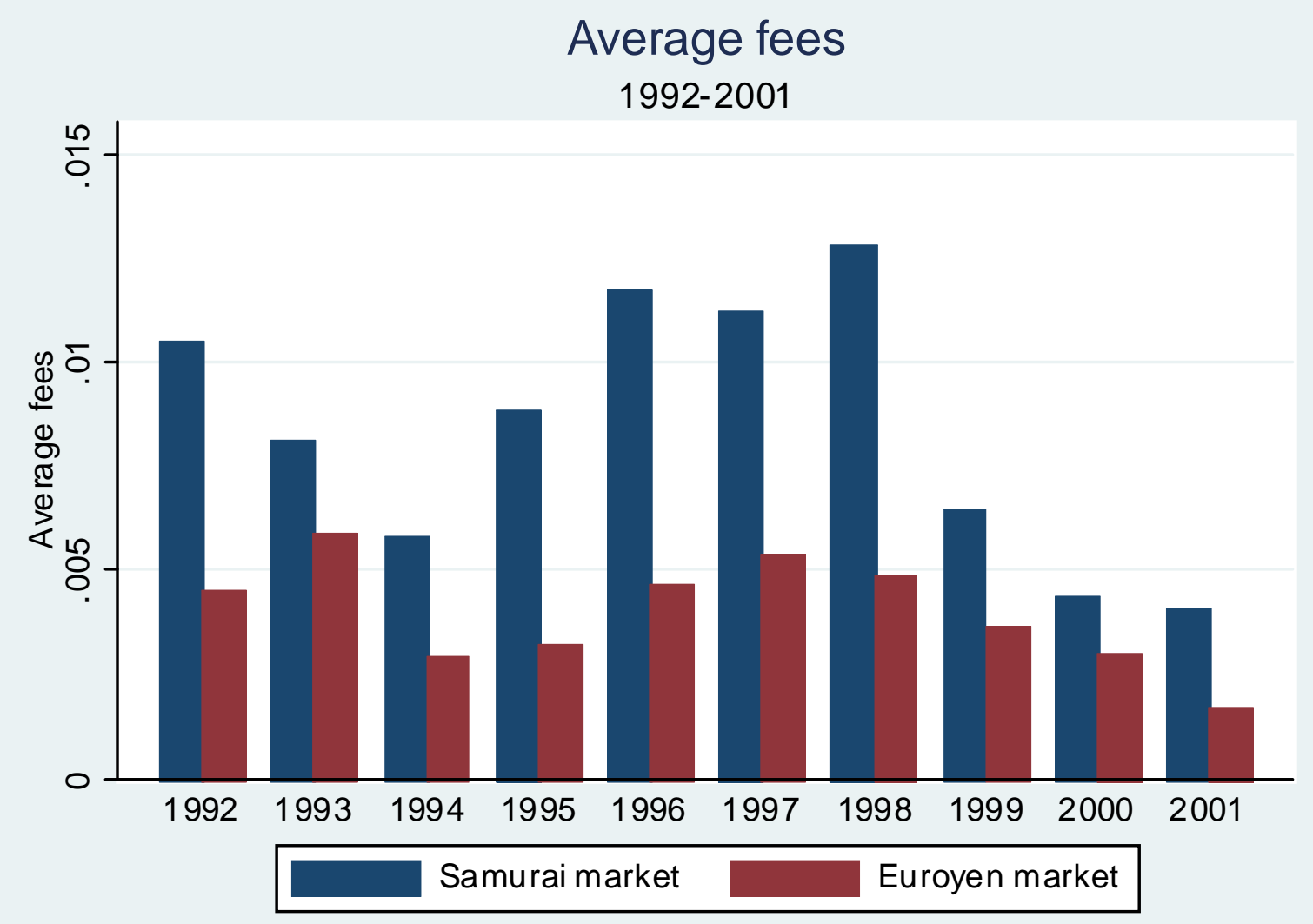

